\title{
Analysis of the School Concept through the Perspectives of Candidate Teachers via Metaphors
}

\author{
Didem DOĞAN*
}

Received: 06 May 2013

Accepted: 10 April 2014

\begin{abstract}
Metaphors, which we often use in our daily-life whether consciously or not, are ornate statements that can reveal hidden meanings in minds. The aim of this study is to put forth mental perceptions of candidate teachers towards the concept of school using metaphors. The participants of the study are candidate teachers studying mathematics teaching, social sciences teaching, science and technology teaching, and English Language Teaching at Aksaray University in 2012-2013 academic year $(n=161)$. As data gathering device, a form prepared to determine the metaphors about school which includes the statement "The school is like ........... because ............." has been used. The data acquired by the data gathering device have been analysed using quantitative and qualitative data solving techniques. According to the findings of the study, candidate teachers have generated 62 metaphors as to the concept of school. Examined as regards with their similarities, nine conceptual categories have come up.
\end{abstract}

Keywords: metaphor, school metaphor, mental image

\section{Extended Abstract}

Purpose and Significance: As distinct from the studies about metaphors, candidate teachers' perceptions about school have been searched out and how these perceptions differ as regards to their branches has been determined. Owing to the fact that the findings of this study display the mental perceptions of candidate teachers before being teachers; the negative perceptions of participants about school before starting their professions and the reasons of this situation have been put forth. As a result, the study provides the opportunity for school principals and higher education administrators to determine the negativities of their organizations and to take precautions to eliminate these negativities. Besides, this study tries to provide teachers with a perspective about how to treat students.

Teachers' negative or positive perceptions of their professions which are among the most important components of our education system will affect intra-classroom activities as well. For this reason, it is important to determine candidate teachers' perceptions of their professions. The main purpose of this study is to determine the prospective teachers' perceptions of school which is the base of their profession. In addition, how candidate teachers' perceptions of teaching profession differ as regards to their branches has been revealed and as a result, the reasons of difference in teachers' mental images about school have been tried to be set forth. Within the framework of this general purpose, answers for the following questions have been sought:

1- What are the metaphors of candidate teachers about the concept of school?

\footnotetext{
* Corresponding author: Research Assistant, Aksaray University, Aksaray, didemdogan@aksaray.edu.tr
} 
2- How can these metaphors be categorized with regards to their common aspects? How do these conceptual categories range with regards to the branches of participants?

Methods: The sample of the study consists of candidate teachers who study in the Faculty of Education at Aksaray University in Spring term of 2012-2013 academic year. The branches of the participants are Mathematics Teaching, Social Sciences Teaching, Science Teaching, And English Language Teaching. The data acquired by the participants' completing the phrase "The school is like .........., because ............." has been analysed using both qualitative and quantitative analysis techniques. The participants of the study are 161 candidate teachers who study in the Faculty of Education at Aksaray University in 2012-2013 academic year.

In order to reveal the metaphors of participants about the concept of school, each participant has been asked to complete the sentence School is like ....... because ....... . For this aim, an empty form with this statement at the top was given to the candidate teachers and they were asked to complete these forms within a class hour. The handwritten ideas of the students/candidate teachers have been used as the main data resource of the study. The metaphors developed by the participants have been analysed at four stages: 1- stage of coding and eliminating 2- stage of collecting sample metaphor image 3- stage of category developing 4- stage of achieving validity and reliability

Reliability in qualitative researches which is akin to inner validity in quantitative researches is an element that allows others' being aware of participants' including interpretations of their experiences directly into the research (Thomas \& Magilvy, 2011). Two important processes have been carried out in this research in order to prove the validity of research results of this study: (1) Data-analysis Process (especially how nine conceptual categories have been acquired) has been explained in detail. (2) For each of 62 metaphors acquired after the research, a sample metaphor image supposed to represent that metaphor best has been determined and all these metaphors have been presented in the section findings. In order to provide the reliability of the research, expert opinion has been asked with the aim of confirming whether metaphor images under nine conceptual categories acquired during the study represent the aforesaid conceptual category. Reliability coefficient calculated according to Huberman's (1994) formula is \%98.

Results: According to the findings of the study, participants created 62 valid metaphors in terms of school concept. Being examined through their common aspects, these metaphors have been organized under nine conceptual categories. These aforesaid nine conceptual categories have been analysed with regards to candidate teachers' branches; besides, their frequencies and percentages have been calculated. According to the findings of the study, it has been revealed that $86,4 \%$ of candidate teachers perceive the school positively. $47(29,1 \%)$ of 161 candidate teachers consider the school as a place of love and interdependence, $31(19,2 \%)$ as a part of life, $22(13,6 \%)$ as a place of disciplinary education, $16(9,9 \%)$ as a place of production, $13(13,6 \%)$ as a place of 
enlightenment and learning, $13(13,6 \%)$ as a place of socializing and development, 12 $(\% 7,4)$ as a hierarchical system which has lost its aim, $7(4,3)$ as a center of career and occupation, $6(3,7 \%)$ as a system and a hierarchical structure.

Discussion and Conclusions: Most of the candidate teachers' $f(47)$ expressing school as a place of love and interdependence and within this context their considering their teachers as their parents and their friends as their brothers and sisters mean that they communicate with their teachers and friends well. Not a few of the candidate teachers $\mathrm{f}(22)$ state that they consider the school as a place of disciplinary education and control and they don't feel well at school. This means they have got negative feelings about school climate.

Given these results, it might be expressed that revealing the mental perceptions of candidate teachers before being active teachers, this study is important as regards with its determining participants' negative perceptions towards the school before they start their profession and the reasons of these negative perceptions, with its giving opportunity for school principals and higher education administrators to determine the negativities of their institutions and to take precautions against these negativities. The study also gives perspective to teachers in terms of how to approach students. 


\title{
Öğretmen Adaylarının Perspektifinden Okul Kavramının Metaforlarla Analizi
}

\author{
Didem DOĞAN
}

Makale Gönderme Tarihi: 06 Mayıs 2013

Makale Kabul Tarihi: 10 Nisan 2014

ÖZET: Günlük hayatta farkında olmadan sık sık kullandığımız metaforlar bireylerin zihinlerinde var olan saklı manaları ortaya çıkarmaya yarayan süslü ifadelerdir. $\mathrm{Bu}$ araştırmanın amacı, metaforları kullanarak öğretmen adaylarının, okul kavramına ilişkin sahip oldukları zihinsel algıları ortaya çıkarmaktır. Araştırmanın katılımcılarını 2012-2013 öğretim y1lında Aksaray Üniversitesinde Eğitim Fakültesinde, matematik, sosyal bilgiler, fen bilgisi ve İngilizce öğretmenliği bölümlerinde öğrenim gören öğretmen adayları $(n=161)$ oluşturmaktadır. Araştırmada veri toplama aracı olarak "Okul ....... gibidir, çünkü ......." ifadesinin yer aldığı, okula ilişkin metaforları tespit etme amacıyla hazırlanmış bir form kullanılmıştır. Veri toplama aracından elde edilen veriler nicel ve nitel veri çözümleme teknikleri kullanılarak analiz edilmiştir. Araştırmadan elde edilen bulgularına göre, öğretmen adayları okul kavramına ilişkin toplam 62 tane metafor üretmişlerdir. Üretilen bu metaforlar benzerlikleri bakımından sınıflandırıldığında 9 farklı kavramsal kategori ortaya çıkmıştır. Bu kavramsal kategoriler öğretmen adaylarının branşlarına göre incelenmiş, okula ilişkin metaforların branşlara göre frekansları ve yüzdelikleri hesaplanmıştır. Araştırmanın sonucuna göre öğretmen adaylarının okula ilişkin algıları genellikle olumludur.

Anahtar sözcükler: metafor, okul metaforu, zihinsel imge

\section{Giriş}

Son dönemlerden dünyada yaşanan teknoloji ve bilgi alanındaki hızlı gelişmeler toplumsal yapımızda değişmelere neden olmuş, bu değişim bireylerin eğitime ve okullara ilişkin algılarını da etkilemiştir. Zira ülkemizin geleceğini getiştiren okullar artık hayatımızın her evresinde daha fazla yer almaktadır. Dolayısıyla okulun tüm paydaşlarının özellikle öğrencilerin, öğretmenlerin ve öğretmen adaylarının okula ilişkin algılarını bilmek eğitim sistemimizin gelişmesi açısından önemlidir. Bu anlamda okula ilişkin algıları ortaya koymak için metaforları kullanmak daha doğru veriler elde etmemizi sağlayacaktır. Çünkü metaforlar bireylerin söylemek istemedikleri olumlu ve olumsuz tüm hisleri de ortaya çıkaran önemli bir araçtır.

İstiare, ödünçleme anlamına gelen (Ayverdi, 2005) ve dilimize Fransızcadan geçen Metafor (metaphore) kelimesi iki farklı kelimeden meydana gelmiştir. Metafor kelimesindeki meta (metha) sözcüğü öte (yahut) ile gibi manalarına gelirken fora (phora) sözcüğü ise aktarmak (nakletmek) manasına gelmektedir (Keklik, 1990). Bu anlamda metaforlar ile doğal olan bir mana mecazi olarak dile getirilmektedir $\mathrm{Bu}$ özelliği ile metaforlar anlamları bir durumdan başka bir duruma dönüştürüp yeni kelimeler ve anlamlar oluşmasını sağlayan önemli araçlardır.

Genellikle süslü söylemler yaratmaktan ibaret sanılan metaforlar aslında pek çok anlamı barındıran, dünyayı kavramamıza yardım eden bir düşünme ve görme biçiminin ortaya çıkmasını sağlar. Metaforların; düşünme tarzı, dilin kullanımı ve bilimin üzerindeki etkisinin yanı sıra, bireyin kendisini ifade edebilme yeteneği üzerinde de biçimlendirici bir etkisi vardır (Morgan, 1980). Günlük hayatımızda iletişim kurarken sık sık kullandığımız metaforlar eğitim hayatımızda da öğrenmenin gerçekleşmesinde soyut olan olguları somutlaştırmaya ve anlaşılır hale getirmeye olanak sağlar. 
Bilginin sunumundaki çeşitli fonksiyonları işletmek için kullanılan (Radman, 1997) metaforlar; eski anlamları yok edip kendiliğinden yeni anlamlar kurarlar, semantik yani anlamsal alanlar arasındaki sınırları durmadan değiştirirler (Şevki, 2009). Anlamın taşınmasıyla yapılan metafor başka bir ifadedeki tecrübenin bir boyutunu anlamamıza izin verir (Eaglestone, 2009). Dolayısıyla metafor bir şeyi başka bir şeyle tanımlama demektir.

Metaforların estetik, süsleyici ve eğitici rollerinin yanı sıra eğitim alanındaki uygulamalarda da önemli bir rol oynamaktadır. Önceleri özellikle edebiyatta kullanılan bu yöntem şimdilerde sosyal bilimler alanına girmiş ve çeşitli çalışmalara konu olmuştur. Eğitimde metaforların rolü ile ilgili iki temel görüş vardır. Bunlardan biri öncelikle metaforların estetik değerler taşıdığıdır ki bu da dilin kullanımında özellikle de edebiyatta kullanılmaktadır. Eğitimde ise metaforlar, estetik özelliklerin kullanımının yanı sıra eğitimde verilecek değerlerin sezdirilmesi açısından da önemlidir (Ortony, 2002). Son dönemlerde metaforlar eğitim araştırmalarında sık sık kullanılmış ve öğrenci, yönetici, öğretmen, araştırma görevlisi gibi kavramlar, eğitimle etkileşim içinde olan bireylerin metaforik algılarıyla ortaya konulmaya çalışılmıştır (Cerit, 2006; Saban, 2008; Güven \& Güven, 2009; Oflaz, 2011; Özdemir, 2012 ).

Metaforlar eğitimi destekleyen teorilerin temelidir. Dolayısıyla eğitimin her kademesinde kullanılabilir. Bu yüzden öğretmenler, eğitimde metaforların rolünü ve önemini kavramak için metaforların kullanımıyla ilgili eğitim almalıdırlar (Botha, 2009). Çünkü metaforlarla öğrencilerin okula, derse ya da öğretmene ilişkin zihinsel algılarını belirlemek mümkündür. $\mathrm{Bu}$ zihinsel imgelerin olumlu ve olumsuz olması eğitimi doğrudan etkilemektedir. Bu bağlamda metaforlar eğitimin içinde uygulamalı olarak kullanılabileceği gibi eğitim sisteminin alt sistemlerine ve bu sistemleri oluşturan tüm unsurlara ilişkin algıların ortaya çıkarılmasında da kullanılabilir.

Ulusal ve uluslararası alan yazında metaforlarla ilgili pek çok çalışma yapılmıştır (Baker, 1991; Radman, 1997; Bromem ve Stahl, 1999; Bredeson, 1988; Cerit, 2006; Ocak ve Gündüz, 2006; Botha, 2009; Eaglestone, 2009; Güven ve Güven, 2009; Oflaz, 2011; Özan ve Demir, 2011). Bu çalışmalar genellikle öğrenci, öğretmen ve müdür kavramlarına (Cerit, 2006; Güven ve Güven, 2009), bazı derslere (Güven ve Güven, 2009; Oflaz, 2011), okul geliştirmeye (Baker, 1991) , okul seçimine (Henig, 1994), kültür (Abdelwali, 2007; Çelikten, 2006; Eder, 2009) ve okul kavramına (Saban, 2008; Özdemir, 2012) yönelik algıların ortaya çıkarılmasına ilişkindir.

Cerit'in (2006) müdür, öğretmen ve öğrenci kavramlarına ilişkin metaforları incelediği çalışmasının bulgularına göre, öğrenciler tarafından orta derecede kabul gören metaforlar müdür kavramı ile ilgilidir. Yöneticilerin ve öğretmenlerin belirttikleri müdür kavramına yönelik metaforlar; control eden, danışman, eğitim uzmanı, koç, orkestra şefi, yönetmen ve lider şeklindedir. Katılımcıların yöneticilerle ilgili orta ve daha düşük düzeyde belirttikleri metaforlar ise; patron, bakıc1, otoriter kişi, kral, anne/baba, bahçıvan ve hâkim metaforlarıdır. Katılımcıların görüşleri ile cinsiyetleri ve eğitim durumları arasında anlamlı bir fark bulunamamışken, kıdemleri ile metaforik görüşleri arasında anlamlı bir fark bulunmuştur. 
Saban'ın (2008) öğretmen, öğrenci ve öğretmen adaylarının okul kavramına ilişkin metaforları incelediği araştırmasında 74 tane geçerli metafor elde edilmiş ve bu metaforlar 10 farklı kavramsal çatı altında toplanmıştır. Adı geçen çalışmanın bulgularına göre öğretmen ve öğretmen adaylarının çoğu okulu kültürleme ve şekillendirme yeri olarak algılamaktadırlar. 10 kavramsal kategori ile katılımcı türü (öğretmen ve öğrenci) ve sınıf düzeyleri (3., 4., ve 5., sınıf) arasında anlamlı bir farklılık tespit edilmiştir.

Özan ve Demir'in (2011) okul kültürü kavramına ilişkin farklı lise türlerinden öğretmen ve öğrencilerin metaforik algılarını belirlemeyi amaçladığı çalışmalarının bulgularına göre katılımcıların okul kültürünü en fazla benzettikleri metafor aile metaforudur. Ayrıca araştırmada öğretmen ve öğrencilerin okul kültürü kavramına yönelik zihinsel algıları arasında anlamlı bir fark tespit edilmiştir.

Özdemir'in (2012) okul kavramına ilişkin lisede okuyan öğrencilerin metaforik algılarını belirlemek amacıyla yaptığı çalışması diğer metafor çalışmalarında farklı olarak nicel teknikler kullanılarak yapılmış ve araştırmada veri toplama aracı olarak "Okul Algısı Ölçeği" kullanılmıştır. Adı geçen araştırmanın bulgularına göre öğrencilerin okul kavramına ilişsin metaforları; koruma ve geliştirme yeri, baskı yeri ve yuva alt boyutlarında cinsiyet, gelir durumu, okul türü ve sınıf değişkenleri arasında anlamlı bir fark bulunmuştur.

Metaforlarla ilgili yapılan çalışmalardan farklı olarak bu çalışmada son dönemlerde yaşanan teknolojik ve bilgi alanındaki değişmelerin öğretmen adaylarının okula ilişkin algılarında farklılık yaratıp yaratmadığını ortaya koyulmuş ve bu algıların onların branşlarına göre nasıl değiştiği belirlenmiştir. Bu araştırmadan elde edilen bulgular öğretmen adaylarının öğretmen olmadan önceki zihinsel algılarını gözler önüne serdiği için araştırmada katılımcıların mesleklerine başlamadan önceki okula ilişkin olumsuz algıları ve bunların sebepleri ortaya konmuştur. Böylece araştırma, okul yöneticilerine ve yüksek öğretim kurumları yöneticilerine kurumlarındaki olumsuzlukları belirleme ve bu olumsuzlukları ortadan kaldıracak önlemler alabilme firsatı sunmaktadır. Ayrıca araştırma, öğretmenlere öğrencilerine nasıl yaklaşmaları gerektiği hususunda bakış açısı sunmaktadır.

Eğitim sistemimizin en önemli unsurlarından biri olan öğretmenlerin mesleklerine ilişkin olumlu ya da olumsuz algıları sınıf içi etkinlikleri de etkileyecektir. $\mathrm{Bu}$ sebeple öğretmen adaylarının mesleklerine ilişkin algılarının belirlenmesi önemlidir. $\mathrm{Bu}$ araştırmanın temel amacı; öğretmen adaylarının okula ilişkin zihinsel imgelerinin ortaya çıkarılarak onların farkındalıklarını artırmaya yardımcı olmak, olası olumsuzlukları onlar sahaya inmeden düzeltmektir. Ayrıca araştırmada öğretmen adaylarının branşlarına göre öğretmenlik mesleğine ilişkin algılarının nasıl bir dağılım gösterdiği de ortaya konmuş, böylece farklı branşlara sahip öğretmenlerin okula ilişkin zihinsel imgelerinin farklılık nedenleri ortaya konmaya çalışılmıştır. Bu genel amaç çerçevesinde üç alt probleme yanıt aranmıştır:

1. Öğretmen adaylarının okul kavramı ile ilgili metaforları nelerdir? 
2. Öğretmen adaylarının okula ilişkin sahip oldukları metaforlar benzer özellikler bakımından nasıl kavramsal kategoriler oluşturur?

3. Oluşturulan kavramsal kategoriler katılımcıların branşlarına göre nasıl bir dağ 11 lım göstermektedir?

\section{Yöntem}

\section{Katılımcilar}

Araştırmanın örneklemini 2012-2013 eğitim-öğretim y1lında Aksaray Üniversitesi Eğitim Fakültesinde öğrenim gören öğretmen adaylarından basit rastlantısal örnekleme yöntemi ile seçilmiş 161 öğretmen adayı oluşturmaktadır. Araştırmaya katılan öğretmen adaylarının demografik özelikleri tablo 1 de verilmiştir.

Tablo 1'e göre araştırmaya 117'si bayan, 44'ü erkek olmak üzere toplam 161 öğretmen adayı katılmıştır. Katılımcıların branşlarına göre dağılımı şöyledir. 22 İngilizce öğretmeni adayının 14'ü bayan (\%63.6), 8'i erkektir (\%36.4) Toplamda 18 tane olan sosyal bilgiler öğretmeni adayının 8'i bayan (\%44.44), 10’u (\%55.56) erkektir. 61 fen bilgisi öğretmeni adayının 44'ü bayan (\%72.13), 17'si (27.87) erkektir. 60 matematik öğretmeni adayının 51'i bayan (\%85), 9'u erkektir (\%15).

Tablo 1

Katılımcıların Branş ve Cinsiyetlerine Göre Dă̆ılımı

\begin{tabular}{llll}
\hline Branş & Cinsiyet & $f$ & $\%$ \\
\hline İngilizce öğretmenliği & $\mathrm{K}$ & 14 & 63.6 \\
& $\mathrm{E}$ & 8 & 36.4 \\
Sosyal bilgiler öğretmenliği & $\mathrm{K}$ & 8 & 44.44 \\
Fen bilgisi öğretmenliği & $\mathrm{E}$ & 10 & 55.56 \\
& $\mathrm{~K}$ & 44 & 72.13 \\
Matematik öğretmenliği & $\mathrm{E}$ & 17 & 27.87 \\
& $\mathrm{~K}$ & 51 & 85 \\
\hline
\end{tabular}

Not: Tablodaki rakamlar Aksaray üniversitesinde eğitim fakültesinde öğrenim gören öğretmen adaylarının branşları göz önüne alınarak belirlenmiştir.

\section{Verilerin Toplanması}

Öğretmen adaylarının okul kavramı ile ilgili zihinlerindeki metaforları belirlemek amacıyla katılımcılara "Okul ......... gibidir, çünkü ..........." cümlesinin bulunduğu bir form verilmiştir. Katılımcılardan formda yer alan boşlukları 
bir ders süresince hissettikleri gibi doldurmaları istenmiştir. $\mathrm{Bu}$ formdan elde edilen veriler araştırmanın veri kaynağını oluşturmuştur.

\section{Verilerin Analiz Edilmesi}

Katılımcılar tarafından üretilen metaforların analizi dört aşamada yapılmıştır (Saban, 2008). Bu aşamalar aşağıda ayrıntılı bir şekilde anlatılmıştır.

1. Kodlama ve eleme aşaması. $\mathrm{Bu}$ aşama öğretmen adayları tarafından geliştirilen metaforların belli bir sıraya konmasını böylece basit ve geçici bir liste oluşturulmasını içermektedir. Bu liste oluşturulurken katılımcıların belirttikleri metaforu açıklama biçimleri ile ifade edebilme becerileri irdelenmiştir. $\mathrm{Bu}$ işlem yapılırken doldurulmayan formlar ve geçersiz sayılan (açıklama ile metaforu birbirine uymayan ya da herhangi bir metaforu içermeyen) formlar $(n=32)$ elenmiştir. Kodlama ve eleme aşamasının amacı, katılımcıların belli bir metaforu net bir şekilde dile getirip getirmediğini tespit ederek, verilerin analizinin ilk basamağını oluşturmak adına üretilen metaforları basit bir şekilde kodlamaktır (örneğin, "yuva”, "hapishane”, "hayat” vb.)

2. Örneklerle metaforları derleme aşaması. Bu aşamada tüm verilerden elde edilen metaforlar incelenmiş ve toplamda 62 farklı metafor elde edilmiştir. $\mathrm{Bu}$ metaforlar sıraya konularak her metaforu temsil eden örnek metafor ifadesini belirlemek amacıyla ham veriler tekrar gözden geçirilmiştir. Bu işlem sonucunda geçerli 62 metaforu en iyi temsil eden ifadelerin listesi yani örnek metafor listesi oluşturulmuştur. Böylece metaforlar belirli bir kategori altında toplanmış, verilerin analizi için ikinci basamak oluşturulmuş ve yorumlanma aşamalarının ilk adımı atılmıştır. Belirtilen listedeki metafor ifadelerini oluşturan ve katılımcılar tarafından belirtilen metaforların gerekçeleri, katılımcıların kendi kelimeleri ve üslupları korunarak aktarılmıştır.

3. Kategori oluşturma aşaması. Bu aşamanın temel amacı üretilen metaforları ortak özellikler bakımından incelemektir. Bu aşamada, bir önceki aşamada geliştirilen örnek metafor listesi göz önünde bulundurulmuş metafor imgelerinin okul kavramını nasıl kavramsallaştırdı̆̆ 1 belirlenmiştir. $\mathrm{Bu}$ işlem yapılırken öğretmen adayları tarafından geliştirilen metaforlar konuları ve kaynakları bakımından analiz edilmiştir. $\mathrm{Bu}$ analizlerin sonucunda metafor imgeleri, okul kavramına ilişkin bakış açısı çerçevesinde ilişkilendirilerek (örneğin; "sıkıntı verici bir yer olarak okul" vb.) 9 farklı kavramsal kategori oluşturulmuştur. Tablo 2 kategori oluşturma aşamasında belirlenen 9 farklı kavramsal kategorinin özelliklerini göstermektedir. 


\section{Tablo 2}

\section{Okul ile ilgili 9 Kavramsal Kategori ve Bu kategorilerin Özellikleri (Özet)}

Sevgi ve dayanışma yeri olarak okul

- Okulda kardeşlik, arkadaşlik, dostluk vardır ve bir aile içerisinde yaşanabilecek her şey yaşanır.

- Okulda aile sıcaklığı vardır.

- Okuldaki bireyler ailemiz gibi ihtiyaçlarımızı gidermeye çalışırlar.

- Okul arkadaşlarımızla sevinçlerimizi ve üzüntülerimizi paylaştığımız yerdir.

Yaşamın bir parçası olarak okul

- Hayatımız okul sayesinde şekillenir.

- Hayata dair her şey okulda tecrübe edilir.

- Okul su ve nefes gibi bir ihtiyaçtır.

- Okul hayat kaynağıdır.

Üretim yeri olarak okul

- Çevresinde ve ailesinde işlenmeye başlayan öğrenci okulda işlenme sürecini tamamlar.

- Birey sanki bir hammadde gibi okula girer ve işlenmiş bir şekilde çıkar.

- Okul dünyaya, yetiştirdiği öğrencilerle katkı sağlar.

Sistemli ve hiyerarşik bir yapı olarak okul

- Okuldaki bütün birimler birbirine bağıml olarak bir düzen içinde çalışır.

- Okulda herkesin ve her bölümün bir görevi vardır, bunlardan biri işlevini yerine getiremezse tüm sistem bozulur.

- Okulda iletişim, karar almalar, görev ve sorumlulukların olduğu sistematik bir yapı vardir.

- Okulda hiyerarşik bir yapı vardır.
Gelişim ve sosyalleşme yeri olarak okul

- Okul bireylerin olgunluğa ulaştığı yerdir.

- Okul Öğrencileri bilgilerle donatarak onları geliştirdiği yerdir.

- Okul bireye bir arada yaşamayı öğretir.

- Okul birden fazla aktiviteyi içererek bireyin sosyalleşmesini sağlar.

Bilgilenme ve aydınlanma yeri olarak okul

- Okul yeni şeyler öğrenilen bir yerdir.

- Okul yaşamı anlamak için öğrenilmesi, gereken şeylerin öğrenildiği yerdir.

- Okul bilgi yuvasıdır.

- Okul bilgilerle donatılmıştır, bu bilgileri almak istediğimizde bize fazlasıyla verilir.

\section{Kariyer ve iş merkezi olarak okul}

- Okul öğrencileri eğitir ve bir meslek sahibi yapar.

- $\quad$ Okul bireye güzel bir gelecek sağlar.

- Okul geleceğin temelidir.

- Okul hayatımızın güvencesidir.

\section{Disiplin edici bir yer olarak okul}

- Okul öğrencileri bunaltan kuralların olduğu bir yerdir.

- Okul dört duvar arasında soğuk ilişkilerin olduğu bir yerdir.

- Okulda bir düzen ve disiplin vardır.

- Okulda bireysel özellikler göz ardı edilir ve tek tip kurallar vardır. Amacını kaybetmiş bir yer olarak okul

- Okulda hedefler vardir ama bu hedeflere bir türlü ulaşılamaz.

- $\quad$ Okul dört duvardan ibarettir.

- Okul ne zaman ne olacağı belli olmayan ve sınavlar yüzünden gerildiğim bir yerdir.

- Okuldaki eğitim gerçek hayattan farklıdır. 
Geçerlik ve güvenirlik. Nicel araştırmalardaki iç geçerliliğe benzeyen nitel araştırmalarda güvenirlik, katılımcıların deneyimlerinin yorumunu araştırmaya doğrudan koyduğunu diğerlerinin fark etmesine izin veren bir elementtir (Thomas ve Magilvy, 2011) Bu araştırmanın sonuçlarının geçerliğini sağlamak amacıyla, verilerin analiz süreci (tema ve kavramsal kategorilerin nasıl oluşturulduğu vb.) şeffaf ve detaylı bir şekilde açıklanmıştır. Ayrıca araştırma bulgularında elde edilen metaforların her biri için onu en iyi temsil ettiği varsayılan örnek metafor listesi oluşturulmuş bu liste oluşturulurken katılımcıların kendi kelimeleri ve anlatım biçimleri kullanılmıştır.

Araştırmanın güvenirliğini sağlamak amacıyla 9 farklı kavramsal kategori altında derlenen metafor imgelerinin belirlenen kategorileri temsil etme durumunu teyit etmek için uzman görüşüne başvurulmuştur. Bu aşamada nitel araştırma tekniklerine vakıf eğitim fakültesinde görev yapan bir öğretim üyesine iki tane liste verilmiştir. Bu listelerin birinde ham metafor imgeleri (hapishane, yuva vb.) diğerinde ise 9 kavramsal kategori yer almıştır. Uzmandan listedeki metaforlar ile 9 kavramsal kategoriyi eşleştirmesi istenmiştir. Daha sonra uzmanın görüşü ile araştırmacının kategorileri karşılaştırılmıştır. Karşılaştırma sonucunda görüş ayrılıkları tespit edilmiş ve görüşüne başvurulan uzmanın sadece bir metaforu ("çaydanlık" metaforunu) farklı bir kategori altına koyduğu belirlenmiştir. Araştırmanın güvenirliği Miles ve Huberman'ın (1994: 64) formülü (Güvenirlik = görüş birliği / görüş birliği + görüş ayrılığ1 X 100) kullanılarak hesaplanmıştır. $\mathrm{Bu}$ formüle göre bu araştırmanın güvenirlik katsayısı [Güvenirlik = $61 /(61+1) \times 100=98) \% 98$ olarak hesaplanmıştır. Bu güvenirlik katsayısı araştırmanın güvenilir olduğunu göstermektedir. Zira Huberman'a göre nitel araştırmalarda uzman ve araştırmacı arasındaki uyum \%90 ve üzerinde olması istenilen güvenirliğin sağlandığı anlamına gelmektedir (Miles ve Huberman, 1994).

\section{Bulgular}

$\mathrm{Bu}$ bölüm genel olarak öğretmen adaylarının sahip oldukları metaforları, bu metaforlarla ilgili kavramsal kategorileri ve bu kategorilerin özeliklerini içermektedir. Bulgular öğretmen adaylarının geliştirdikleri metafor imgeleriyle desteklenerek verilmiştir.

\section{Genel Bulgular}

Araştırmanın birinci alt probleminde yer alan "Öğretmen adaylarının okul kavramı ile ilgili sahip oldukları metaforlar nelerdir?" şeklinde ifade edilen alt probleme ilişkin elde edilen bulgulara göre öğretmen adaylarının okul kavramı ile ilgili ürettikleri geçerli metafor sayısı 62'dir (bakınız Tablo 3). Bu 62 metaforun 7 tanesi (yuva, aile, ev, kapı komşusu, futbol takımı, han, tiyatro) sevgi ve dayanışma yeri olarak okul kategorisini, 7 tanesi (hayat, dünya, su, bağımlılık, çaydanlık, nefes, geçmiş) yaşamın bir parçası olarak okul kategorisini, 10 tanesi ( hapishane, korku filmi, zorlayıcı bir yer, yetimhane, kafes, hayvanat bahçesi, kapsül, fare kapanı, cehennem, eşek) disiplin edici bir yer olarak okul kategorisini, 5 tanesi (fabrika, toprak, şirket, sanayi, saat atölyesi) üretim yeri olarak okul kategorisini, 8 tanesi (eğitim kurumu, kütüphane, bilgi merkezi, baba, kumbara, bilgisayar, market, roman) bilgilenme aydinlanma yeri olarak okul 
kategorisini, 9 tanesi (dört duvar, ayak bağı, dipsiz kuyu, zaman kaybı, yıkılmış dünya, saat, kovan, makine, sistem) amacını kaybetmiş bir yer olarak okul kategorisini, 6 tanesi (gelecek, köprü, iş, arı, garanti, işsizlik kurumu) kariyer ve iş merkezi olarak okul kategorisini, 10 tanesi (toplantı salonu, örümcek, ağaç, insan, değirmen, kafe, tecrübe, oyun evi, sosyal tesis, çiçek bahçesi) gelişim ve sosyalleşme yeri olarak okul kategorisini oluşturmaktadır. Buna ek olarak, toplam 62 metafordan 34 tanesi (kapı komşusu, futbol takımı, han, tiyatro, kapı komşusu, futbol takımı, han, tiyatro, baba, kumbara, bilgisayar, market, roman, sanayi, saat atölyesi, ayak bă̆g, dipsiz kuyu, zaman kaybı, yıkılmış dünya, makine, sistem, köprü, iş, arı, garanti, işsizlik kurumu, örümcek, ăgaç, insan, değirmen, oyun evi, sosyal tesis, çiçek bahçesi, ) tek bir katılımcı tarafından üretilmiştir.

Araştırmaya katılan 161 öğretmen adayının 47'si $(\% 29,1)$ okulu sevgi ve dayanışma yeri olarak, 31'i $(\% 19,2)$ okulu yaşamın bir parçası olarak, 22'si $(\% 13,6)$ okulu disiplin edici bir yer olarak,16'sı $(\% 9,9)$ okulu bir üretim yeri olarak, 13'ü $(\% 13,6)$ okulu bilgilendirme ve aydınlanma yeri olarak, 13 'ü $(\% 13,6)$ okulu gelişim ve sosyalleşme yeri olarak, 12'si $(\% 7,4)$ okulu amacını kaybetmiş hiyerarşik bir yapı olarak, 7'si $(\% 4,3)$ okulu kariyer ve iş merkezi olarak ve 6'sı $(\% 3,7)$ okulu sistemli ve hiyerarşik bir yapı olarak algılamaktadırlar.

\section{Kavramsal Kategorinin Oluşumu}

Araştırmanın ikinci alt probleminde yer alan "Öğretmen adaylarının okula ilişkin sahip oldukları metaforlar benzer özellikler bakımından nasıl kavramsal kategoriler oluşturur?" şeklinde ifade edilen alt probleme ilişkin bulgular şöyledir: Kategoriler oluşturulurken öğrencilerin kullandıkları metaforun türü ve gerekçeleri göz önüne alınmıştır. $\mathrm{Bu}$ kategoriler belirlenirken öğrencilerin kullandıkları cümleler hiç değiştirilmeden doğrudan konulmuştur. Ayrıca, metaforu üreten öğretmen adayına ilişkin kişisel bilgiler ilgili metafor ifadesinin yanında parantez içinde kodlanmıştır. Bu kodlar katılımcılarla ilgili üç bilgiyi içermektedir.

1. Katılımcıların branşları. Metafor imgesini üreten öğretmen adaylarının branşları matematik öğretmenliği (Mat.), sosyal bilgiler öğretmenliği (Sos.), fen bilgisi öğretmenliği (Fen.) İngilizce öğretmenliği (İng.) şeklinde kodlanmıştır.

2. Katılımcıların cinsiyetleri. Öğretmen adaylarının cinsiyetleri branşlarının yanına E ve K harfleri kullanılarak kodlanmıştır.

3. Katılımcıların yaşları. Öğretmen adaylarının yaşları cinsiyetlerinin yanına rakamla yazılmıştır.

Kategorilere ait örnekler verilirken katılımcı sayısının fazla olması sebebiyle tüm katılımcıların cevaplarını ayrı ayrı yazmak yerine kategoriyi oluşturan metaforu en iyi temsil ettiği varsayılan ifadeleri yazan katılımcıların yanıtları kullanılmıştır. Tablo 3 'te 9 kavramsal kategorinin metaforlara göre dağılımı gösterilmektedir. 
Tablo 3

Dokuz Kavramsal Kategorinin Metaforlara Göre Dă̆ılımı

\begin{tabular}{|c|c|c|c|c|c|}
\hline Kategoriler(n=9) & $f$ & $\%$ & Metaforlar $(\mathrm{n}=62)$ & $f$ & $\%$ \\
\hline $\begin{array}{l}\text { Sevgi ve dayanışma } \\
\text { yeri olarak okul }\end{array}$ & 47 & 29.1 & $\begin{array}{l}\text { aile (18), yuva (16), ev (9), kapı komşusu (1), } \\
\text { futbol takımı (1), han (1), tiyatro (1) }\end{array}$ & 7 & 11.2 \\
\hline $\begin{array}{l}\text { Yaşamın bir parçası } \\
\text { olarak okul }\end{array}$ & 31 & 19.2 & $\begin{array}{l}\text { Hayat (15), dünya (6), su (3), bağımlılık(2), } \\
\text { çaydanlık (2), nefes (1), geçmiş (2) }\end{array}$ & 7 & 11.2 \\
\hline $\begin{array}{l}\text { Disiplin edici bir yeri } \\
\text { olarak okul }\end{array}$ & 22 & 13.6 & $\begin{array}{l}\text { Hapishane (10), korku filmi (2), zorlayıcı bir yer } \\
\text { (3), yetimhane (1), kafes (1), hayvanat bahçesi } \\
\text { (1), kapsül (1), fare kapanı (1), cehennem (1), } \\
\text { eşek (1) }\end{array}$ & 10 & 6.1 \\
\hline $\begin{array}{l}\text { Üretim yeri olarak } \\
\text { okul }\end{array}$ & 16 & 9.9 & $\begin{array}{l}\text { Fabrika (7), toprak (4), şirket (3), sanayi (1), } \\
\text { saat atölyesi (1) }\end{array}$ & 5 & 8.1 \\
\hline $\begin{array}{l}\text { Bilgilenme ve } \\
\text { aydınlanma yeri olarak } \\
\text { okul }\end{array}$ & 13 & 8 & $\begin{array}{l}\text { Eğitim kurumu (3), kütüphane (3), bilgi merkezi } \\
\text { (2), baba (1), kumbara (1), bilgisayar (1), market } \\
\text { (1), roman (1) }\end{array}$ & 8 & 12.9 \\
\hline $\begin{array}{l}\text { Gelişim ve } \\
\text { sosyalleşme yeri } \\
\text { olarak okul }\end{array}$ & 13 & 8 & $\begin{array}{l}\text { Toplantı salonu (2), örümcek (1), ağaç (1), insan } \\
\text { (1), değirmen (1) kafe (2), tecrübe (2), oyun } \\
\text { evi(1), sosyal tesis (1), çiçek bahçesi (1) }\end{array}$ & 10 & 16.1 \\
\hline $\begin{array}{l}\text { Amacını kaybetmiş } \\
\text { hiyerarşik bir yapı } \\
\text { olarak okul }\end{array}$ & 12 & 7.4 & $\begin{array}{l}\text { Dört duvar (2), ayak bağı (1), dipsiz kuyu (1), } \\
\text { zaman kaybı (1), yıkılmış dünya (1), Saat (2), } \\
\text { kovan (2), makine (1), sistem (1) }\end{array}$ & 9 & 14.5 \\
\hline $\begin{array}{l}\text { Kariyer ve iş merkezi } \\
\text { olarak okul }\end{array}$ & 7 & 4.3 & $\begin{array}{l}\text { Gelecek (2), köprü (1), iş (1), arı (1), garanti (1), } \\
\text { işsizlik kurumu (1) }\end{array}$ & 6 & 9.6 \\
\hline $\begin{array}{l}\text { Sistemli ve hiyerarşik } \\
\text { bir yapı olarak okul }\end{array}$ & 6 & 3.7 & Saat (2), kovan (2), makine (1), sistem (1) & 4 & 6.4 \\
\hline
\end{tabular}

Sevgi ve dayanışma yeri olarak okul. Öğretmen adaylarından 47 tanesi (\%29.1) okulu sevgi ve dayanışma yeri olarak algılarken bu kategoriye 62 metafordan 7 tanesi (\%11.2) girmektedir. Bu metaforlar yuva $\mathrm{f}(16)$, aile $\mathrm{f}(18)$, ev $\mathrm{f}(9)$, kapı komşusu $\mathrm{f}(1)$, futbol takımı $\mathrm{f}(1)$, han $\mathrm{f}(1)$, tiyatro $\mathrm{f}(1)$ şeklindedir. Bu kategorideki metaforlar aşağıdaki özellikleri göstermektedir.

1. Okulda öğretmenlerimiz anne babamız gibidir. Onlar bizleri sürekli iyiye yönlendirir, hata yaptığımızda ise bizleri uyarırlar. (Mat. K, 19)

2. Okulda iyi arkadaşlıklar kurulur. (Mat. K, 20)

3. Okul insana huzur, güven ve sıcak bir ortam sağlar. (Mat. K, 20)

4. Okul çocuğa aile şefkatini hissettirir. Çocuk zamanının çoğunu ailesinin yanında ve okulda geçirir, okulda aile ortamını yaşar. (Mat. K, 20)

5. Günümüzün yarısını nasıl ailemizle geçiriyorsak belli bir dönemden sonra da hayatımızın yarısını okulda geçiriyoruz. Birçok şeyi okulda yaşıyoruz ve hayatımızın en güzel evrelerini okulda geçiriyoruz. (Mat. K, 19) 
6. Öğrenci ailesinde öğrenemediği bazı bilgileri ve kuralları okulda öğrenir. Örneğin annemiz ve babamı bize merhametli olmamızı öğütler biz bu öğrendiğimiz davranışı okulda uygularız. (Mat. K, 22)

7. Okul benim ikinci yuvam. Annem babam derdimi sıkıntımı dinlemez belki ama okuldaki erkek öğretmenlerim ağabeyim ve babam, bayan öğretmenlerim ise bir abla ve anne gibidir. Öğretmenlerimle herhangi bir etkinlik yapmak, evde oturup anne babamla konuşmaktan daha zevkli geliyor bana. (Mat. E, 21)

8. Okulda her şey yaşanır; kardeşlik, arkadaşlık, dostluk, kavga, sevgi, saygı yani bir aile içerisinde olabilecek her şey okulda ve sınıfta meydana gelir. (Fen. K, 21)

9. Okul benim ailem gibi, nasıl evde bir sıkıntım olduğunda ailemle paylaşıyorsam okulda da sıkıntılarımı öğretmenlerim ve arkadaşlarımla paylaşıyorum. (Sos. K, 23)

10. Okula başladığımız andan itibaren yeni insanlarla tanışırız ve onları ailemizin bir parçası olarak görürüz. Kimi zaman sınıf arkadaşımızı gerçek ailemizden daha fazla görürüz. Arkadaşlarımızla sıkıntımızı, üzüntülerimizi ve sevinçlerimizi paylaşırız. Benim için okul kocaman bir ailedir. (Fen. E, 21)

11. Okulda bir öğrenme, saygı-sevgi, hayatın varlığı, birlik, dayanışma vardır. (Sos. E, 22)

Yaşamın bir parçası olarak okul. Öğretmen adaylarından 31 tanesi (\%19.2) okulu yaşamanın bir parçası olarak algılamaktadırlar. Bu kategorinin içinde 62 metafordan 7 tanesi (\%11.2) yer almaktadır. Bu metaforlar; hayat $f(15)$, dünya $f(6)$, su $\mathrm{f}(3)$, bağımlılık $\mathrm{f}(2)$, çaydanlık $\mathrm{f}(2)$, nefes $\mathrm{f}(1)$, geçmiş $\mathrm{f}(2)$ şeklindedir. Bu kategorideki metaforlar aşağıdaki özellikleri göstermektedir.

1. Okul sadece matematik fizik, kimya gibi derslerden ibaret değildir. Okul aynı zamanda bizi hayata hazırlayan, bize hayatı öğreten ve kişiliğimizi oluşturmamızı sağlayan bir kurumdur. (İng. K, 22)

2. Okul su gibi bir ihtiyaçtır. (Mat. K, 20)

3. Okul insana hayatı öğreten, onu hayata bağlayan tek yerdir. (Mat. E, 22)

4. Okul dünya gibi hayatın içindedir. Biz nasıl dünyadan ibaretsek dünya da okuldan ibarettir. (Mat. K, 20)

5. Hayatta olduğu gibi okulda da zorluklar yaşarız ama okul hayatını yaşamadan gerçek yaşamınız şekillenmez. (Fen K, 22)

6. İnsan hayata sıfırdan başlar ve hayatta düşe kalka bazen iyi günler bazen kötü günler geçirir. Belli noktadan sonra zamanı gelince bu dünyadan göçüp gider. İnsan okula sıfırdan başlar bazen iyi notlar alır, bazen kötü. Eğitimini tamamlayınca mezun olur. (Sos. K. 20)

7. Okul da hayatta karşılaştı̆̆ımız tüm sorunlarla karşılaşırız. Fizyolojik ihtiyaçlarımızdan tutun keşfetme ve merak ihtiyaçlarımıza kadar her türlü ihtiyacımızın giderildiği yerdir. Okul hayata hazırlık değil hayatın ta kendisidir. (Sos. K, 22) 
8. İnsan fiziksel ihtiyaçlarını gidermezse düşüncelerini gerçekleştiremez ve sosyalleşemez, yaşadığı hayat ona çok boş gelir. İşte okul tüm bu ihtiyaçların karşılandığg yerdir. (Sos. E, 23)

9. Okul bizim için bir ihtiyaçtır ve iyi bir hayat sürmemiz için gereklidir. Okul olmadan yaşam düşünülemez. Okul bizim temel ihtiyacımızdır. (Fen. K, 21)

10. Hayatla ilgili her şey okulda tecrübe edilir. (Fen. K, 22)

Disiplin edici bir yeri olarak okul. Öğretmen adaylarından 22 tanesi (\%13.6) okulu disiplin edici bir yer olarak algılamaktadır. Bu kategoride 62 metafordan 10 tanesi (\%16.2) yer almaktadır. Bu metaforlar; hapishane $\mathrm{f}(10)$, korku filmi $\mathrm{f}(2)$, zorlayıc bir yer $\mathrm{f}(3)$, yetimhane $\mathrm{f}(1)$, kafes $\mathrm{f}(1)$, hayvanat bahçesi $\mathrm{f}(1)$, kapsül $\mathrm{f}(1)$, fare kapanı $\mathrm{f}(1)$, cehennem $f(1)$, eşek $f(1)$ şeklindedir. Bu kategorideki metaforların temel özellikleri aşağıda sunulmuştur.

1. Okul kurallarla doludur. Mesela tek tip giyinmek, takı takmamak, saç toplamak, sakal kesmek gibi okul öğrencinin bir birey olduğunun unutulduğu yerdir. Okul kişisel özeliklerin göz ardı edildiği yerdir. (İng. K. 21)

2. Okulda herkes aynı üniformayı giyer belli kurallar vardır ve bu kurallara uymayan ceza alır. (İng. K, 20)

3. Okul yapmam gereken şeyleri sürekli ertelememe sebep olan bir yerdir. (İng. K. 23)

4. Okul ne zaman ne olacağı belli olmayan ve sınavlar yüzünden öğrencinin sürekli gerilim yaşadığı bir yerdir. (Mat. K, 19)

5. Öğrencilerin içine girince daralıp bunaldığı ve sıkıldığı bir an önce uzaklaşmak istediği bir yerdir okul. (Mat. K, 20)

6. Her türlü zorlamanın var olduğu bir yerdir okul. Çoğu şeyin zorla yaptırıldığı, bireyin özgürlüğünün kısıtlandığı yerdir okul. (Mat. K. 20)

7. Okulda anne ve babadan uzaksın ve hep öğretmen ve müdürlerin emrindesin. Okulda kurallarla yatılıp kurallarla kalkılır. (Mat. E, 21)

8. Okul içerisinde öğrencinin aktif olmadığı sadece öğretmenin aktif olduğu soğuk bir kurumdur. (Sos. K, 22)

9. Okul bireyin belli bir yaşa gelmesine rağmen hala istediği şeyi yapamadığı, her şeyin zorla ve kurallarla yaptırıldığı yerdir. (Fen .Bil. Öğr. K 19)

Üretim yeri olarak okul. Öğretmen adaylarından 16 tanesi (\%9.9) okulu üretim yeri olarak algilamaktadırlar. $\mathrm{Bu}$ kategoride 62 metafordan 5 tanesi (\%8.1) bulunmaktadır. Bu kategoriyi oluşturan metaforlar şunlardır; fabrika $\mathrm{f}(7)$, toprak $\mathrm{f}(4)$, şirket(3), sanayi $\mathrm{f}(1)$, saat atölyesi $\mathrm{f}(1)$. Bu kategorideki metaforların temel özellikleri aşağıda verilmiştir.

1. İşlenmemiş olarak gelen öğrenciler burada işlenip bir sanat eserine dönüşürler. (İng. K, 21)

2. Okul tıpk1 toprak gibi, dünyaya yetiştirdiği öğrenciler ile katkı sağlar. (Mat. K, 20) 
3. Nasıl fabrikaya önce işlenmemiş hammadde girer ve işlendikten sonra işe yarayan bir ürün ortaya çıkarsa okulda da öğrenci bir hammadde gibidir sonuçta işlenir ve bilgiyle donanmış bir eleman olarak çıkar. (Mat. K, 19)

4. Nasıl toprak bağrında binlerce çeşit tohum barındırıp filiz ve meyve verirse okul da binlerce öğrenciyi bağrında barındırır ve onları doktor, mühendis vb. olarak yetiştirir. (Sos. E, 22)

5. Okulda öğrenci en sade hali ile başak tanesi gibidir. Okul değirmen gibi onları öğütür ve yeni bir ürün ortaya çıkarır. (Fen. E 21)

6. Okula gelen öğrenciler, dünyayı ve kendilerini değiştirmek amacıyla okula gelirler, okul onları yoğurarak şekil verir ve özellik kazandırır. (Fen. E. 23)

Bilgilenme aydınlanma yeri olarak okul. Araştırmaya katılan 161 öğretmen adayından 13 tanesi (\%8) okulu bilgilenme ve aydınlanma yeri olarak algılamaktadırlar. Bu kategoriyi 62 metafordan 8 tanesi (\%12.9) oluşturmaktadır. Bu metaforlar; eğitim kurumu $f(3)$, kütüphane $f(3)$, bilgi merkezi $f(2)$, baba $f(1)$, kumbara $f(1)$, bilgisayar $f(1)$, market $\mathrm{f}(1)$, roman $\mathrm{f}(1)$ metaforları şeklindedir. Bu kategorideki metaforların temel özellikleri aşağıda verilmiştir.

1. Okul kütüphane gibi bilgi yüklüdür. Biz o bilgileri almak istediğimiz sürece bize fazlasıyla verilir. (Mat. K, 10)

2. Okulda bilgi birikimi sağlanır ve bu bilgi birikimi bizim hayatımızı kolaylaştırır. (Mat. K, 21)

3. Öğrenci okul sayesinde belli bir bilgi seviyesine ulaşır. (Fen. K, 20)

4. İnsan doğumdan ölüme kadar bir eğitim alma çabası içindedir bunun ilk adımı da okuldur. (Fen. E, 20)

5. Hayatla ve kendi alanımla ilgili tüm bilgileri okulda alırız. Yaşamımızda gerekli olan bilgilerin büyük bir çoğunluğunu okul sayesinde ediniriz. (Fen. E, 19)

6. Öğrenci bilmediği ve öğrenmek istediği şeyleri okulda araştırarak öğrenir. (Fen. K, 19)

7. Birey pek çok şeyi okulda öğrenir ve bu öğrendikleriyle çevresini aydınlatır. (Fen. E, 18)

8. Okul bilgisayar gibidir, gerekli her tür bilgi içindedir ancak kullanmayı bilemezseniz hiçbir şey öğrenemezsiniz. (Mat. K, 20)

Gelişim ve sosyalleşme yeri olarak okul. 161 öğretmen adayından 13 tanesi (\%8) okulu gelişim ve sosyalleşme yeri olarak algılamaktadır. Bu kategoriyi 62 metafordan 10 tanesi (\%16.2) oluşturmaktadır. Bu metaforlar; toplantı salonu $\mathrm{f}(2)$, örümcek $\mathrm{f}(1)$, ağaç $\mathrm{f}(1)$, insan $\mathrm{f}(1)$,değirmen $\mathrm{f}(1)$ kafe $\mathrm{f}(2)$, tecrübe $\mathrm{f}(2)$, oyun evi $\mathrm{f}(1)$, sosyal tesis $\mathrm{f}(1)$, çiçek bahçesi $\mathrm{f}(1)$ şeklindedir. Bu kategorideki metaforların temel özellikleri aşağıda verilmiştir.

1. Okul bireylerin kendilerini özgürce ifade etme olanağı bulduğu yegâne kurumdur. (İng. K, 22) 
2. Okulda renk renk kişilikler vardır. Okul sosyal bir ortamdır ve her türlü insanla (değişik kişilikler, değişik düşünceler, mimikleri ve ses tonları) tanışıyor ve kaynaşıyoruz. (Sos. E, 22)

3. Öğrenci okulda yetişir, her yönüyle burada şekillenir, gerek fiziksel gerekse düşünce yönünden burada büyür ve gelişir. (Sos. K, 23)

4. Okul sayesinde öğrenciler bireysel ve grup halinde becerilerini yansıtırlar ve sonuca ulaşırlar. (İng. K, 22)

5. Okul pek çok aktiviteyi içinde barındıran gelişim ve sosyalleşme yeridir. (Mat. K, 19)

6. Okul bireyleri bir amaç için toplar ve onların kendilerini geliştirmelerine ve onların sosyalleşmelerine olanak sağlar. (Mat. K, 22)

7. Okul bireye tıpkı bir baba gibi ayakları üzerinde durabilmesini ve yürümesini öğretir. (Mat. K, 21)

8. Sorumluluk sahibi olma, paylaşma, insanlarla iyi geçinme gibi pek çok şeyi okul sayesinde öğreniriz. (Fen. K, 18)

9. Okul insanlara kendilerini her açıdan yetiştirip geliştirme imkânı sağlar. İnsanlar okul sayesinde kendilerini daha iyi tanır ve yeteneklerinin farkına varır. Okul insanları hayata yönlendirir ve onlara yeni ufuklar açar. (İng. K, 20)

Amacını kaybetmiş hiyerarşik bir yapı olarak okul. Öğretmen adaylarından 12 tanesi (\%7.4) okulu amacını kaybetmiş bir yer olarak algılamaktadırlar. Bu kategoride 9 (\%14) metafor yer almaktadır. Bu metaforlar; dört duvar $\mathrm{f}(2)$, ayak bağ $f(1)$, dipsiz kuyu $f(1)$, zaman kaybı $f(1)$, yıkılmış dünya $f(1)$, saat $f(2)$, kovan $f(2)$, makine $\mathrm{f}(1)$, sistem $\mathrm{f}(1)$ şeklindedir. Bu kategorideki metaforların temel özellikleri aşağıda verilmiştir.

1. Okul sonuçlarının ne olduğu belli olmayan, hedefleri sözde olan ama ona ulaşı1ıp ulaşılmadığı belli olmayan amaçsız bir kurumdur. (Fen. K, 23)

2. Okul amacını yitirmiş bir yerdir. Kimyası değişmiş olduğu için onu düzeltmek çok zordur. (Mat. K, 21)

3. Okulda fabrika üretimi gibi tek tip ve sabit fikirli bireyler yetiştiriliyor. (Mat. E, 22)

4. Okulda şimdiki hayatımda ve gelecekte kullanmayacağım pek çok gereksiz bilgi veriliyor, bunların ne amaçla verildiği konusunda öğrenciler bilgilendirilmiyor. (Mat. K, 21)

Kariyer ve iş merkezi olarak okul. Araştırmaya katılan 161 öğretmen adayından 7 tanesi (\%4.3) okulu kariyer ve iş merkezi olarak algılamaktadırlar. Bu kategoride 62 metafordan 6 tanesi (\%9.6) yer almaktadir. Bu metaforlar; gelecek $\mathrm{f}(2)$, köprü $\mathrm{f}(1)$, iş $\mathrm{f}(1)$, arı $\mathrm{f}(1)$, garanti $\mathrm{f}(1)$, işsizlik kurumu $\mathrm{f}(1)$ şeklindedir. Bu kategorideki metaforların temel özellikleri aşağıda verilmiştir.

1. Okul geçmişimiz ve geleceğimizdir. (Mat. K, 20)

2. Derslere çalışmak, dersleri dinlemek ve başarmak öğrencinin görevidir.

Öğrenci bu görevi yerine getirmek için okula gider. (Mat. K, 21) 
3. Okul bireye güzel bir gelecek veren bir kurumdur. (Fen. K, 23)

4. Okul bireyleri işler, eğitir ve onları meslek sahibi yapar. (Fen. E, 25)

5. Okul okuyup hayatımızı kurtarmamızı sağlar, ayrıca okuyup kariyer yaparak gelecekteki yerimizi de belirleriz. (Fen. K, 18)

Sistemli ve hiyerarşik bir yapı olarak okul. Araştırmaya katılan 161 öğretmen adayından 6 tanesi (\%3.7) okulu sistemli ve hiyerarşik bir yapı olarak algılamaktadır. Bu kategoride 62 metafordan 4 tanesi (\%6.4) yer almaktadır. Bu metaforlar; saat $\mathrm{f}(2)$, kovan $\mathrm{f}(2)$, makine $\mathrm{f}(1)$, sistem $\mathrm{f}(1)$ şeklindedir. Bu kategorideki metaforların temel özellikleri aşağıda verilmiştir.

1. Okulda herkes her ne kadar aynı amaç için toplanmış olsa da herkesin farklı rolleri ve görevleri vardır. (İng. K, 25)

2. Okuldaki her bölümün ayrı ayrı görevleri vardır ve herhangi bir bölümdeki eksiklikler tüm sistemi etkiler. (Sos. E, 21)

3. Okullarda ast üst ilişkisi vardır. Bu hiyerarşide müdürler en üstte iken ikinci sırada öğretmenler, en alt sırada ise öğrenciler yer alıyor. (Mat. K, 20)

4. Okuldaki tüm birimler belli bir düzen içinde ve birbirine bağlı bir şekilde çalışırlar. (Fen. E, 23)

\section{Öğretmen Adaylarının Okula İlişkin Metaforlarının Branşlarına Göre} Dağılımı. Araştırmanın üçüncü alt probleminde yer alan " Oluşturulan kavramsal kategoriler katılımcıların branşlarına göre nasıl bir dağılım göstermektedir?" şseklinde ifade edilen alt probleme ilişkin bulgular şöyledir. Öğretmen adaylarının okula ilişkin metaforlarının branşlarına göre dağılımı tablo 4'de verilmiştir. 
Tablo 4

Dokuz Kavramsal Kategorinin Branşlara Göre Frekans ve Yüzdeleri

\begin{tabular}{|c|c|c|c|c|c|c|c|c|}
\hline \multirow[t]{2}{*}{ Kavramlar } & \multicolumn{2}{|c|}{ İng. Öğr. } & \multicolumn{2}{|c|}{ Sos. Öğr } & \multicolumn{2}{|c|}{ Fen Öğr. } & \multicolumn{2}{|c|}{ Mat. Öğr. } \\
\hline & $f$ & $\%$ & $f$ & $\%$ & $f$ & $\%$ & $f$ & $\%$ \\
\hline Sevgi ve dayanışma yeri olarak okul & 6 & 22,2 & 3 & 16,6 & 16 & 26,2 & 14 & 23,3 \\
\hline $\begin{array}{l}\text { Gelişim ve Sosyalleşme sağlayan bir yer } \\
\text { olarak okul }\end{array}$ & 2 & 9,09 & 1 & 5,5 & 7 & 11,4 & 8 & 13,3 \\
\hline Yaşamın bir parçası olarak okul & 2 & 9,09 & 3 & 16,6 & 8 & 13,1 & 7 & 11,6 \\
\hline Bilgilenme aydınlanma yeri olarak okul & 2 & 9,09 & 1 & 5,5 & 7 & 11,4 & 6 & 10 \\
\hline Üretim yeri olarak okul & 3 & 13,6 & 4 & 22,2 & 6 & 9,8 & 4 & 6,6 \\
\hline Kariyer ve iş merkezi olarak okul & 1 & 4,5 & 0 & 0 & 4 & 6,5 & 3 & 5 \\
\hline $\begin{array}{l}\text { Sistemli ve hiyerarşik bir yapı olarak } \\
\text { okul }\end{array}$ & 2 & 9,09 & 0 & 0 & 4 & 6,5 & 5 & 8,33 \\
\hline Disiplin edici bir yeri olarak okul & 3 & 13,6 & 5 & 27,7 & 5 & 8,1 & 6 & 10 \\
\hline Amacını kaybetmiş bir yer olarak okul & 1 & 4,5 & 1 & 5,5 & 4 & 6,5 & 7 & 11,6 \\
\hline Toplam & 22 & & 18 & & 61 & & 60 & \\
\hline
\end{tabular}

Tabloya göre, araştırmaya katılan 22 İngilizce öğretmeni adayının 6 tanesi (\%22.2) okulu sevgi ve dayanışma yeri olarak, 3’er (\%13.6) tanesi ise okulu üretim yeri, yaşamın bir parçası ve sosyalleşme ve gelişim yeri olarak algılamaktadırlar. Okulla ilgili olumsuz algıları barındıran ve okulu disiplin edici bir yer olarak tanımlayan İngilizce öğretmeni adayı sayısı da 3 (\%13.6) tanedir. Branşları İngilizce öğretmenliği olan katılımcılardan sadece $2(\% 9)$ tanesi okulu sistemli hiyerarşik bir yapr olarak algılarken,1 (\%4.5) tanesi okulu amacını yitirmiş bir yer olarak tanımlamışlardır.

Araştırmaya katılan 18 sosyal bilgiler öğretmeni adayının 5 tanesi (\%27.7) okulu disiplin edici bir yer olarak, 4 tanesi (\%22.2) bir üretim yeri olarak algilamaktadırlar. Bu gruptaki katılımciların 3'er tanesi (\%16.6) okulu sevgi ve dayanışma yeri ve yaşamın bir parçası olarak tanımlamışlardır. Sosyal bilgiler öğretmen adaylarının sadece 1'er tanesi (\%5.5) okulu sosyalleşme-gelişim ve bilgilenme-aydınlanma yeri olarak ifade etmişlerdir.

61 fen bilgisi öğretmeni adayının 16'sı (\%26.2) okulu sevgi ve dayanışma yeri olarak algılarken, 7'si (\%11.4) okulu gelişim ve sosyalleşme yeri, 8’i (\%13.1) yaşamın bir parçası olarak algılamaktadırlar. Bu grup katılımcıların 4'er tanesi (\%6.5) okulu kariyer ve iş merkezi, 4'ü (\%6.5) sistemli hiyerarşik bir yapı, 4’ü (\%6.5) amacını yitirmiş bir yer olarak tanımlamıştır.

Araştırmaya katılan 60 matematik öğretmeni adayının 14'ü (\%23.3) okulu sevgi ve dayanışma yeri, 8'i (\%13.3) gelişim ve sosyalleşme yeri olarak ifade ederken 7'şer aday (\%11.6) okulu yaşamın bir parçası ve amacını yitirmiş bir yer olarak 
tanımlamıştır. $\mathrm{Bu}$ grup öğretmen adaylarının sadece 3 tanesi (\%5) okulu kariyer ve iş merkezi olarak algılamışlardır.

Tablo 4'de okulu amacını kaybetmiş bir yer olarak belirten öğretmen adayları incelendiğinde, branşı matematik olan adayların bu kategoriyi belirten diğer tüm katılımcıların toplamından daha yüksek düzeyde $f(7) \quad$ (\%11.6) algıladıkları görülmektedir.

\section{Sonuç ve Tartışma}

Araştırmadan elde ettiğimiz bulgulara göre öğretmen adaylarının \%86.4’ü okulu olumlu manada algılamaktadırlar. Literatürü incelediğimizde öğretmenler ve öğrenciler üzerinde yapılan araştırmalarda katılımcıların okula ilişsin algıları genellikle olumludur (Cerit, 2006; Saban, 2008; Tuncay ve Özçınar, 2009; Özdemir, 2012).

Cerit'in (2006) öğrenci, öğretmen ve müdürlerin algılarına göre okul kavramına ilişkin metaforları incelediği araştırmadan elde edilen bulgulara göre katılımcılar okulu daha çok bilgi ve aydınlanma yeri, büyüme ve olgunlaşma yeri, değişme ve ilerleme yeri, aile ve takım olarak belirtmişlerdir. Cerit'in (2006) bulgusu bu araştırmanın bulguları ile örtüşmektedir. Zira bu araştırmada katılımcıların \%12.9 si okulu bilgi ve aydınlanma yeri olarak belirtirken, öğretmen adaylarının \%11.2 si okulu aile ( $\mathrm{f}=18)$ ve yuva $(\mathrm{f}=16)$ metaforlarının yer aldığı sevgi ve dayanışma yeri olarak algılamaktadırlar. Diğer taraftan Cerit'in (2006) bulgusuna göre katılımcıların tercih etmedikleri zihinsel imgeler "karmaşa ortami", "hapishane", "fabrika", “iş yeri” ve "alışveriş merkezi" metaforlardır. $\mathrm{Bu}$ araştırmadan elde ettiğimiz bulgularda ise katılımcıların $(\mathrm{f}=22)$ \%13.6's1 okulu disiplin edici bir yer olarak okul kategorisi içinde yer alan hapishane, kafes, cehennem gibi olumsuz metaforlar kullanmışlardır. Cerit'in (2006) bulgularıyla bizim bulgularımız arasındaki bu küçük fark araştırmanın yapıldığı okulun fiziksel özelliklerinden ya da araştırmanın farklı okul türlerinde yapılmış olmasından kaynaklanmış olabilir.

Saban'ın (2008) okul kavramına ilişkin metaforları belirlemek amacıyla öğretmen, öğrenci ve öğretmen adayları üzerinde yaptığı araştırma bulguları ile bizim bulgularımız kısmen paralellik göstermektedir. Adı geçen araştırmada katılımcılar tarafından okul kavramı ile ilgili toplamda 74 tane metafor geliştirilmiştir. $\mathrm{Bu}$ metaforlar benzer özellikler bakımından incelendiğinde ise 10 farklı kategori oluşturulmuştur. Saban'ın (2008) yapmış olduğu kategoriler incelendiğinde "bilgi ve aydınlanma yeri olarak okul” kategorisine (bu kategori içerisinde aile ( $f=89$ ) ve takım ( $f=9)$ metaforları yer almakta ve bu katılımcıların \%16.2'si görüşünü yansıtmıştır. Bizim yaptığımız araştırmanın bulgusuna göre ise bu kategoriye katılım oranı \%12.9'dur. Diğer taraftan adı geçen araştırmada sevgi ve dayanışma yeri olarak okul kategorisi katılımcıların \%9.4'ünün algılarını yansıtırken bizim araştırmamızın bulgularında bu kategoriyi algılama oranı \%11.2'dir. Diğer taraftan bizim araştırma bulgularımızda \%4.3 olarak tespit ettiğimiz iş ve çalışma merkezi olarak okul kategorisi Saban'ın (2008) çalışmasındaki katılımcıların \%4.4'nün görüşlerini yansıtmaktadır. Dolayısıyla Saban'ın 10 kategorisinden üç tanesi bizim araştırmamızın bulguları benzerlik göstermektedir. 
Özan ve Demir'in (2011) farklı lise türlerine göre öğretmen ve öğrencilerin okul kültürü ile ilgili algılarını metaforlar aracılığıyla belirlemek amacıyla yaptığı çalışmasına göre okul kültürü ile ilgili en sık kullanılan metafor, "aile" metaforu olmuştur, bu bulgu da bizim bulgularımızı destekler niteliktedir.

Özdemir'in (2012) lise öğrencileri üzerinde yaptığı ve metaforları nicel yöntemlerle ölçtüğü araştırmasının sonuçlarına göre öğrenciler okulu geliştirme ve koruma yeri olarak yüksek düzeyde algılamışlardır. Aksine öğrencilerin en düşük algıladıkları boyut ise baskı yeri olarak okul boyutudur. $\mathrm{Bu}$ bulgular bizim araştırmamızın bulgularıyla benzerlik göstermektedir. Zira öğretmen adaylarının \%13.6 s1 okulu disiplin edici ve baskıcı bir yer olarak algılarken \%7.4'ü ise okulu amacını yitirmiş bir yapının olarak ifade etmiştir.

Sonuç olarak Öğretmen adaylarının büyük bir kısmının f(47) okulu sevgi ve dayanışma yeri olarak ifade etmeleri ve bu bağlamda öğretmenlerini anne-baba, arkadaşlarını da kardeşleri gibi görmeleri, öğrencilerin okulda öğretmenleri ve arkadaşları ile iyi iletişim kurdukları anlamına gelir. Ayrıca öğretmen adaylarının en fazla katılım gösterdikleri ve okulu sevgi ve dayanışma yeri olarak algılamaları (aile, yuva) onların okulu sevmelerinin ve okulda olumlu bir iklim hissettiklerinin bir göstergesidir. Ayrıca öğretmen adaylarının ikinci sırada okula atfettikleri kategorinin okul yaşamın bir parçası $\mathrm{f}(31)$ olması öğretmen adaylarının okula ve dolayısıyla eğitim ve öğretime verdiklerini önemi ortaya koymaktadır.

Öğretmen adaylarının küçük bir kısmının $\mathrm{f}(7)$ okulu kariyer ve iş merkezi olarak görmesi de öğretmen adaylarının okulu para ve kariyer kazanma yeri olarak görmekten çok öğrenme, aydınlanma yeri ve hayatın içinde olması gereken dayanışma yeri olarak gördükleri anlamına gelmektedir.

Öğretmen adaylarının azımsanmayacak kısmının $\mathrm{f}(22)$ okulu disiplin ve kontrol edici bir yer olarak görmesi ve okulda kendilerini çok da iyi hissetmediklerini ifade etmeleri onların okul iklimine ilişkin olumsuz düşünceleri olduğunu ortaya koymaktadir.

\section{Öneriler}

Okulu olumsuz hisseden öğrenci sayısı azımsanmayacak kadar fazladır. öğrencilerin rahatsız olduğu konular tespit edilmeli ve okulu geliştirme ve iyileştirmeye dönük çalışmalar yapılmalıdır. Öğretmenler metaforları, öğrencilerin zihinlerinde geliştirdikleri imajları anlayabilmek için eğitimde sık sık kullanmalıdır. Eğitimciler metaforları bir dersin konusunun ya da anahtar kelimelerinin öğrencide uyandırdı̆̆ anlamı ortaya çıkarmak için kullanılabileceği gibi, öğrencilerin derse, öğretmene, okula ya da arkadaşlarına ilişkin tutumlarını ya da düşüncelerini anlamak için de kullanabilir.

Metaforları eğitimin içinde sık sık kullanmanın yararlarını ortaya koymaya yönelik araştırmalar yapılabilir böylece metaforların önemi daha iyi anlaşılabilir. Ayrıca öğretmen adaylarının kendi branşlarına ilişkin metaforik algılarını belirlemek adına çalışmalar yapılabilir. 


\section{Kaynakça}

Abdelwali M. (2007). Metaphor, simile, culture: beyond the linguistic expression.Saarbrücken: VDM Verlag.

Ayverdi, İ. (2005). Misalli büyük Türkçe sözlük. İstanbul: Kubbealtı.

Baker, P. J. (1991) Mindful Engagement: Metaphors for School Improvoment. The Education Digest, 32-35.

Botha, E. (2009) Why Metaphor Matters in Education. South African Journal of Education, 431-444.

Bredeson, P. (1988) Perspectives on schools: Metaphors and management in education. Journal of Educational Administration, 293-310. Farklı okul türüne göre okul kültürü metaforuna ilişkin algı düzeyleri.

Brommeand, R., \& Stahl, E. (1999) Spatial metaphors and writing hypertexts: Study within schools. European Journal of Psychology of Education Volume 14, Issue 2, pp 267-281

Cerit, Y. (2006) School Metaphors: The Views of The Students, Teachers and Administors. Eğitim Bilimleri:Teori ve Uygulama, 3-13.

Çelikten, M. (2006). Kültür ve öğretmen metaforları. Sosyal Bilimler Enstitüsü Dergisi. 269-283 s.

Eaglestone, R. (2009). Metaphors and Figures Of Speech (Cilt 1). Canada: Taylor\&Francis.

Eder, K.(2009). Metaphor and cultur. Germany: Grin Verlag.

Güven, S., \& Güven, B. (2009). İlköğretim öğrencilerinin sosyal bilgiler dersinde metafor oluşturma becerilerine ilişkin nicel bir araştırma. Kastamonu Eğitim Dergisi. 503-512.

Henig, J. R. ( 1994). Rethinking School Choice: Limits of the Market Metaphor. United Kingdom: Princeton University Press.

Keklik, N. (1990). Felsefede Metafor: Felsefe Problemlerinin Metafor Yoluyla Açıklanması (Cilt 1) İstanbul: Edebiyat Fakültesi Yayınevi.

Miles, M. B. \& Huberman, A. M. (1994). Qualitative data analysis: An expanded sourcebook. (2nd Edition) Calif. : SAGE Publications.

Morgan, G. (1980). Paradigms, Metaphors, and Puzzle Solving in Organizational Analysis. Administrative Science Quarterly, 605-622.

Ocak, G., \& Gündüz, M. (2006). Eğitim fakültelerini kazanan öğretmen adaylarının öğretmenlik mesleğine giriş dersini almadan önce ve aldıktan sonra öğretmenlik mesleği hakkındaki metaforlarının karşılaştırılması. Sosyal Bilimler Dergisi, 293310.

Oflaz, G. (2011). Illköğretim öğrencilerinin "matematik" ve "matematik öğretmeni" kavramlarına ilşikin metaforik algıları. Ankara: Siyasal Kitapevi. 
Ortony, A. (2002). Metaphor and thought. United Kingdom: Cambridge University Press.

Özan, M. B., \& Demir, C. (2011). Farklı okul türüne göre okul kültürü metaforuna ilişkin algı düzeyleri. Ĕ̆itim Yönetim 106-126.

Özdemir, M. (2012) Lise öğrencilerinin metaforik okul algılarının çeşitli değişkenler açısından incelenmesi. Eğitim ve Bilim,213-224.

Radman, Z. (1997) Metaphors: Figures of the minds. Netherlands: Kluwer Akademic.

Saban, A. (2008) Okula ilişkin Metaforlar. Kuram ve Uygulamada Eğitim Yönetimi, 459-496.

Şevki, A. (2009) Edebiyat ve yorum. Ankara: Havuz Yayınları.

Thomas, E., \& Magilvy, J. K. (2011). Scientific inquiry qualitative rigor or research validity in qualitative research. Journal for Specialists in Pediatric Nursing.

Tuncay, N., \& Özçınar, Z. (2009) Distance education students' “metaphors”. Procedia Social and Behavioral Sciences. 